\title{
Tam Sayıların Modellenmesine İlişkin Durum Çalışması
}

\author{
Yurdagül ÇEVİK ${ }^{1}$ (D) , Ahmet CİHANGİR ${ }^{2}$ iD
}

${ }^{1}$ Milli Ĕ̆itim Bakanlı̆̆l, Afyonkarahisar, Türkiye, yrdglcvk03@gmail.com

${ }^{2}$ Necmettin Erbakan Üniversitesi, Konya,Türkiye, acihangir@erbakan.edu.tr

\begin{tabular}{|c|c|}
\hline Makale Bilgileri & ÖZ \\
\hline $\begin{array}{l}\text { Makale Geçmişi } \\
\text { Geliş: } 30.03 .2020 \\
\text { Kabul: } 19.09 .2020 \\
\text { Yayın: 29.12.2020 } \\
\text { Anahtar Kelimeler: } \\
\text { Tam Sayılar } \\
\text { Modelleme } \\
\text { Durum Çalışması }\end{array}$ & $\begin{array}{l}\text { Bu araştırmada, tam sayılar konusunun modellenmesine ilişkin öğretmen görüşlerinin ortaya konulması } \\
\text { amaçlanmıştır. Araştırmada, nitel araştırma yöntemlerinden örnek olay yöntemi kullanılmıştır. Araştırmanın } \\
\text { evrenini, 2014-2015 öğretim yılında Afyonkarahisar ilinin Emirdağ ilçesinde görev yapmakta olan toplam } \\
17 \text { İlköğretim Matematik Öğretmeni oluşturmuştur. } 17 \text { öğretmenden } 15 \text { öğretmene ulaşılmıştır. Araştırmacı } \\
\text { ve iki öğretim üyesi tarafından hazırlanan, açı uçlu soruların yer aldığı bir görüşme formu hazırlanmıştır. } \\
\text { Öğretmenlerle yarı yapılandırılmış görüşme yapılmıştır. Öğretmenlerle yapılan görüşmeler sonucunda elde } \\
\text { edilen verilerin analizinde nitel araştırmalarda kullanılan betimsel analiz yöntemi kullanılmıştır. Bu } \\
\text { araştırmada matematik öğretmenlerinin; modellemenin faydalarının farkında oldukları, eksik yönleri } \\
\text { olduğunu düşünmedikleri ve farklı modelleme yöntemleri arayışı içinde olmadıkları sonuçlarına ulaşıllmıştır. }\end{array}$ \\
\hline
\end{tabular}

\section{Case Study of Modelling of Integers}

\begin{tabular}{ll} 
Article Info & ABSTRACT \\
\hline Article History & $\begin{array}{l}\text { In this research, it was tried to reveal the opinions of the teachers about modeling of the integers. In the } \\
\text { research, a screening model of qualitative research methods was used to reveal existing situation. The } \\
\text { Received: } 30.03 .2020\end{array}$ \\
$\begin{array}{l}\text { Accepted: } 19.09 .2020 \\
\text { publation of the study consisted of 17 primary school mathematics teachers working in Emirdag district of } \\
\text { Published: } 29.12 .2020\end{array}$ & $\begin{array}{l}\text { Afyonkarahisar province in 2014-2015 academic year. 15 teachers were reached from 17 teachers. An } \\
\text { interview form was prepared by the researcher and two faculty members with open-ended questions. Semi- } \\
\text { structured interviews were conducted with the teachers. The descriptive analysis method used in qualitative } \\
\text { Keywords: }\end{array}$ \\
$\begin{array}{l}\text { Integers } \\
\text { results were that mathematics teachers were aware of the benefits of modeling, did not think they were } \\
\text { Modelling }\end{array}$ & $\begin{array}{l}\text { missing, and were not looking for different modeling methods. Suggestions have been developed in the } \\
\text { direction of the obtained results. }\end{array}$ \\
Case Study &
\end{tabular}

"This article is licensed under a Creative Commons Attribution-NonCommercial 4.0 International License (CC BY-NC 4.0)"

Atıf/Citation: Çevik, Y. \& Cihangir, A. (2020). Tam Sayıların Modellenmesine İlişkin Durum Çalışması, Necmettin Erbakan Üniversitesi Ereğli Eğitim Fakültesi Dergisi, 2(2), 136-151. 


\section{GíRiş}

Türk Dil Kurumunun internet sitesinde Matematik; "Aritmetik, cebir, geometri gibi sayı ve ölçü temeline dayanarak niceliklerin özelliklerini inceleyen bilimlerin ortak adı" olarak tanımlanmaktadır. Ayrıca matematik kelimesi Yunanca da "ben bilirim" anlamına da gelmektedir. Bu tanıma göre matematik bilmek insana özgüven aşılamaktadır.

Matematikle ilgilenenlerin, bilgi ve ilgi düzeylerinin farklı olmasından dolayı farklı anlayışlar ve yaklaşımlar ortaya çıkmıştır. Örneğin Reyse ve Ark. (1988) matematiği; yapıların ve ilişkilerin bir çalışması olarak tanımlamışlardır. Yani matematikte bir önceki kavram anlaşılmadığı sürece ondan sonra gelecek kavramın anlaşılması zor olacaktır. Çünkü konular arasında müfredat bütünlüğü sağlayan ilişkiler mevcuttur. Matematikteki yapılar arasındaki ilişkiler, soyutlamaların ön şart ilişkileridir (Akt.; Güneş, 2010: 5). Dolayısıyla matematik yığılmalı olarak ilerleyen bir bilimdir.

Matematik, tanımlanmış olan terim ve sembolleri dikkatli bir şekilde kullanan, öğrencinin zamanla daha iyi anlayabildiği yeni bir dildir (Güneş, 2010: 5). Ayrıca matematik bir düşünme yoludur. Sonuca ulaşılması kadar o sonuca giden yolda önemlidir. Hedefe ancak doğru yollar kullanılırsa ulaşılabilir.

Matematik, insanların ihtiyaçlarından ortaya çıkmış, insanların hayatının her anında yer alan, hayatını kolaylaştıran bir yapıdır. Herkese göre farklı bir anlam taşıyan matematik, genel anlamda insanların yaşamını kolaylaştıran, sayı ve sembollerden oluşan evrensel bir dildir.

Matematik öğrenme bireye sadece bilgi kazandırmaz. Matematik öğrenmek bireye çok yönlü düşünme becerisi kazandırır. Bunun yanı sıra bireyin daha hızlı ve mantıksal bir çerçevede düşünmesini sağlar. Matematik öğrenmenin bireye kazandırdıkları göz önüne alınırsa matematik eğitimi ve öğretimi önemlidir.

Eğitimin amacı geçmişte, bireye sadece bilgi ve beceri kazandırmak iken; günümüzde ise bu bilgi ve beceriyi nerede ve nasıl kazanabileceğini bireye öğretmek, sürekli değişen toplum koşullarına uyum sağlayabilecek her türlü soruna yeni çözümler getirebilecek bireyler yetiştirmektir (Köroğlu ve Yeşildere, 2004: 38). Başka bir deyişle günümüz eğitiminde; bilgiyi sadece öğrenen değil, öğrendiği bilgiyi kullanabilen bireyler yetiştirmek amaçlanmaktadır.

Eğitimin amacının değişmesinden ve genişlemesinden dolayı, matematik eğitiminin kazandırdıkları da farklılaşmaktadır. MEB'da (2006), Matematik eğitiminin bireylere fiziksel dünyayı ve sosyal etkileşimleri anlamaya yardımcı olacak geniş bir bilgi ve beceri donanımı sağladığını belirtmektedir. Matematik eğitiminin bireylere; çeşitli deneyimlerini analiz edebilecekleri, açıklayabilecekleri, tahminde bulunabilecekleri ve problem çözebilecekleri sistematik bir dil kazandıracağı belirtilmektedir. Ayrıca yaratıcı düşünmeyi kolaylaştırdığı ve estetik gelişimi sağladığı ifade edilmektedir. Ek olarak çeşitli matematiksel durumlarının incelendiği ortamlar oluşturarak bireylerin akıl yürütme becerilerinin gelişmesini hızlandırdığı da belirtilmektedir (MEB 2006; Akt.; Ertuğrul, 2009: 9-10).

Van de Walle'ye (1989) göre matematiğin yapısına uygun bir eğitim; öğrencilerin matematikle ilgili kavramları, işlemleri ve kavramlar ile işlemler arasındaki ilişkiyi anlamalarına yardımcı olmaya yönelik olmalıdır (Akt.; Ertuğrul, 2009: 9). Yani matematik eğitimi, matematikte bilgiyi ezberlemekten ziyade matematiğin mantı̆̆ını kavramaya yönelik olmalıdır. Günlük hayatta kullanılabilir bilgiler verebilmelidir.

Matematiğin yapısına uygun bir eğitim verilebilmesi için, programının da bu yapıya uygun olarak düzenlenmesi gerekmektedir. Ayrıca, Kaya (2007); ilköğretim yıllarının çocukların fiziksel ve zihinsel yönden çok hızlı geliştikleri bir döneme rastladığını ifade etmektedir. Çocukların gelişimlerindeki bu değişim ilköğretim matematiğinin; içerik, yöntem, araç-gereç yönünden titizlikle düzenlenmesini zorunlu hale getirmektedir (Akt.; Ertuğrul, 2009: 9).

Olkun ve Toluk (2003) daha önceki matematik programında (MEB, 1998); sezgisel ve informal bilgilere yer 
verilmeden, ivedilikle formal tanımların verilmeye çalışıldığını belirtmektedir. Ayrıca öğrencinin katılımı, kendi çözüm yollarını ve stratejilerini oluşturma ve paylaşma firsatlarının hemen hemen hiç olmadığı da belirtilmektedir. Ek olarak, matematik öğretimi ve matematik kavramlarının ele alınışının içerikten ve somut deneyimlerden yoksun olduğunu vurgulamaktadır (Ertuğrul, 2009: 7).

Bu bağlamda 2005 yılı Matematik Programı ele alınmış ve köklü değişikler yapılmıştır. "Her çocuk matematiği öğrenebilir" ilkesi temel alınarak, matematiksel kavramların veriliş sırası çocukların gelişim düzeyine uygun olarak yeniden düzenlenmiştir. Bu yeniden düzenlenen matematik programında amaç; kişiye günlük yaşamın gerektirdiği matematik bilgi ve beceriyi kazandırmak, ona problem çözmeyi öğretmek ve olayları problem yaklaşımı içinde ele alan bir düşünme biçimi kazandırmaktır (Çiltaş ve Işık, 2013: 1181).

\section{Matematik Öğretiminde Karşılaşılan Sorunlar ve Çözümleri}

Matematik öğretimi alanında yapılan araştırmalar; birçok öğrenci ve öğretmen adayının matematiksel kavram ve süreçleri anlamlandırmada sorunlar yaşadıklarını ortaya koymaktadır (Cankoy, 2005: 63). Ortaya çıkan bu sorunları çözebilmek için öncelikle sorunun kaynağı belirlenmelidir. Soruna temel oluşturan etmenler ortadan kaldırıldığında sorunda direkt olarak çözülmüş olacaktır.

Bunlardan ilki, matematiğin soyut yapısıdır. Öğrenciler, sınıf ortamında öğrendikleri matematiği günlük hayatta nerede ve nasıl kullanacakları konusunda güçlükler yaşamaktadırlar. Bu yüzden matematik öğretiminde kavramların daha anlamlı ve anlaşılır hale gelebilmesi için günlük hayattan örnekler verilerek veya günlük hayatla bağdaşacak şekilde modellemeler yapılarak anlatılması gerekmektedir.

Matematik öğretiminde karşılaşılan sorunlardan birisi de öğrencilerin matematiğe karşı olumsuz tutumu ve ön yargısıdır. Öğrenci; daha okula başlamadan matematiğin zor bir ders olduğuna ve herkesin başarılı olamayacağına inandırılmaktadır. Öğrencinin aklına yerleşen bu düşünce, onun matematikten korkmasına neden olur ve onu matematikten uzaklaştırır. Bu ön yargı giderilmezse öğrenilmiş çaresizlik gerçekleşir. Bu noktada öğrencilerimize, matematiğin günlük hayatla ilişkisinden bahsedilmelidir. Ayrıca konular sınıf seviyesine uygun olarak anlatılmalıdır. Öğretmenler; öğrencilerine seviyelerine uygun ve yapabilecekleri sorular sormalıdır. Bu da öğrencilerin kendilerine güvenlerini sağlamalıdır.

Günlük hayatla bu kadar iç içe olan ve etkinliklerle eğlenceli hale getirmenin mümkün olduğu matematik dersinin; sevilmeyen ders olmasında konuların anlatımlarında kullanılan yanlış öğretim yöntem ve tekniklerinin de etkisi vardır. Bu yüzden öğretme faaliyeti planlanırken; öğrencilerin bireysel farklılıkları, bireysel ihtiyaçları, ilgileri, kültürleri ve sosyo-ekonomik durumları dikkate alınmalı ve öğrenci mümkün olduğunca aktif olmalıdır

\section{Tam Sayılar}

Öğrenciler okul öncesinden başlayarak öğrenimleri boyunca sayılarla iç içedir. Matematiğin temelini sayılar oluşturur. Sayıların insanların ihtiyaçlarından dolayı ortaya çıktığı açıktır.

Her geçen gün insanların ihtiyaçları farklılaşmaktadır. İlk önce sayma ihtiyacından, sayma sayıları ortaya çıkmıştır. Daha sonra sayma sayıları kümesine yokluğu ifade etmek için kullanılan 0 (Sıfır) eklenerek (genişleyerek), doğal sayılar kümesi oluşturulmuştur. Zamanla günlük yaşantımızda, ihtiyaçların giderilmesinde ve problemlerin çözümlenmesinde doğal sayılar yetersiz kalmaya başlamıştır. Sürecin sonunda da tam sayılar kümesine ulaşılmıştır.

Tam sayılar kümesi; pozitif tam sayılar (sayma sayıları) kümesi, sıfır elemanından ibaret küme ve negatif tam sayılar kümesi biçiminde üç ayrık kümenin birleşimi olarak da ifade edilebilir. Pozitif tam sayıları öğrenmede öğrenciler, daha önceden hakkında bilgi sahibi oldukları "sayma sayıları" kavramından yararlanmaktadırlar. Sıfırı ise doğal sayıların şemasıyla öğrenilmektedir. Ancak "negatif tam sayı" kavramının anlaşılabilmesi için daha önceki öğretiminden yararlanabilecek bir ön öğrenme yoktur. 


\section{Tam Sayıların Öğretiminde Kullanılan Yöntemler}

MEB tarafından 2018 yılında yenilenen İlköğretim Matematik Dersi Öğretim Programına göre, öğrenciler tam sayılarla ilk olarak altıncı sınıfta karşılaşacaktır. Konunun en zor anlaşılan kısmı olan "tam sayılarda dört işlem konusu" yedinci sınıfa aktarılarak öğrencinin soyut kavramları daha net anladığı döneme denk getirilmeye çalışılmıştır.

Tam sayıların kavranması ve tam sayılarla yapılan işlemlerin anlamlandırılması, daha sonraki matematik işlemlerinde öğrencilere yol göstermesi bakımından üzerinde durulması gereken bir konudur. Matematiğin yığılmalı bir bilim olması da bunu gerektirmektedir. Tam sayılar konusunun öğretilmesinde soyut kavramların somutlaştırılarak, kavramların anlamlı olarak yapılandırılmasının sağlanması ayrıca önem taşmaktadır.

Yenilenen 2018 Matematik dersi öğretim programında tam sayıların öğretiminde günlük hayattan örnekler verilmesi önerilerek; kar-zarar, bütçe hazırlama, borç-alacak, termometre, asansör vb. örnekler üzerinde durulmuştur. Bunlara ek olarak tam sayılar ve tam sayılarda işlemelerin modellenebilmesi için sayı doğrusu ve sayma pullarının kullanılmasının da uygun olacağı belirtilmiştir (Bozkurt ve Polat, 2011: 788).

Yeni konu ya da yeni bir sayı türü söz konusu olduğunda öğrencilerin aşina oldukları bağlamları kullanmak önemlidir. Böylece öğrenciler önceki bilgilerini kullanarak yeni anlamlar oluştururlar. Öğrenciler karşılaştırmayı ve işlem yapmayı öğrenirken düşüncelerini bir yere oturtmak ve cevaplarını temellendirmek için bağlamlar kullanılabilir. Tam sayılarda bağlamların bazıları nicelik içerirken bazıları da doğrusaldır (Van de Walle, 2018: 479).

Van de Walle (2018) nicelik içeren bağlamları golf puanları, borç ve alacaklar; doğrusal bağlamları sıcaklık, yükseklik, zaman çizelgesi olarak belirlemiştir. (Van de Walle, 2018: 479-480). Ülkemizde öğrencilerin yaşadıkları çevreye göre bu bağlamlardan uygun olanın seçilmesi doğru olacaktır.

Ayrıca Van de Walle’ye (2018) göre tam sayıların öğretiminde iki farklı model kullanılabilir. Bunlar sayı doğrusu ve sayma pullarıdır.

\section{YÖNTEM}

Bu bölümde araştırmanın modeli, evreni ve örneklemi ile verilerin toplanması, veri toplama araçları, uygulama süreci, verilerin çözümlenmesi ve araştırmanın geçerliliği ve güvenirliği hakkında bilgiler yer almaktadır.

\section{Araştırma Modeli}

Araştırma modeli; “... araştırma amacına uygun ve ekonomik olarak, verilerin toplanması ve çözümlenebilmesi için gerekli koşulların düzenlenmesi” dir (Selltiz vd., 1959. Akt.; Karasar, 2014: 76).

Araştırma modeli; nicel, nitel ve her iki yönteminde bir arada kullanıldığı karma model olmak üzere üçe ayrılır. Nicel çalışmalarda "Ne" ve "Ne Kadar" türünden kapalı uçlu ve durum tespitini amaçlayan sorulara yanıt aranır. Nitel çalışmalarda ise temel amaç sayısal veriler üzerinden "Ne" ve "Ne Kadar" sorularına cevap üretmekten ziyade olgu ve olayları doğal yapısı içerisinde ve daha derinlemesine incelemektir. "Nitel çalışma yapan araştırmacılar, üzerinde çalıştı̆̆ kitlenin ayrıntılı bir betimlemesini yapmayı ve üzerinde çalışılan konuyu katılımcıların bakış açısıyla incelemeyi hedefler” (Kuş, 2009. Akt. Koç Şanlı, 2018: 63). Araştırmamızda nitel araştırma yöntemi kullanılmıştır.

$\mathrm{Bu}$ araştırmada; öğretmenlerin tam sayılar konusunu nasıl anlattığı, model kullanıp kullanmadığı, kullandığ1 modellerin faydaları ve eksik yönleri, farklı modeller hakkındaki bilgileri hakkında derinlemesine bir inceleme yapılmıştır. Bu yüzden tam sayılar konusunun modellenmesi ilişkin öğretmen görüşlerini elde etmek adına nitel araştırma yöntemlerinden biri olan örnek olay (durum çalışması) çalışması yapılmıştır.

Örnek olay, araştırmacıların olaylar üzerindeki kontrolünün yetersiz olduğu ve çıkış noktasının gerçek hayat ile ilişkili olduğu durumlarda tercih edilen, daha çok neden ve nasıl sorularının cevaplarının arandığı 
derinlemesine araştırmalarda kullanılan bir yöntemdir (Yin, 2003: Akt.; Dündar, Akyol, 2014: 365).

\section{Çalışma Grubu}

Bu araştırmanın çalı̧̧ma grubu; aynı bölgede görev yapan, hizmet yılları, cinsiyetleri ve çalıştıkları kurumlar gözetilerek belirlenen Ortaokul Matematik öğretmenlerinden oluşmaktadır. Bu bağlamda Afyonkarahisar İli, Emirdă̆ İlçe Milli Eğitim Müdürlüğüne bağlı eğitim kurumlarında görev yapan ortaokul matematik öğretmenleri araştırmanın evrenini oluşturmaktadır.

Araştırmanın evrenini; Afyonkarahisar İli, Emirdağ ilçesinde 6. ve 7. Sınıflara matematik dersi veren toplam 17 matematik öğretmeni oluşturmaktadır. Evrenin tamamına ulaşılmaya çalışılsa da 17 öğretmenden 15 tanesine ulaşılarak araştırma yapılmıştır.

\section{Veri Toplama Araçları ve Süreçleri}

Araştırmada veri toplama aracı olarak, açık uçlu sorulardan oluşan görüşme formu kullanılmıştır. Görüşme formundaki sorular, araştırma sorusuna aranan cevapları elde etme amacı dikkate alınarak hazırlanmıştır. Hazırlanan sorular, alanında uzman iki öğretim üyesi tarafından incelenmiştir. Gerekli düzeltmeler yapılarak, soruların geçerlik ve güvenirliği sağlanmaya çalışılmıştır. Veri toplama aracı 5 sorudan oluşmaktadır. Görüşme formundaki araştırma problemi ve alt problemlerle ilgili olarak açık uçlu toplam 5 soru yer almaktadır.

Uygulanacak görüşme formu, açık uçlu sorulardan oluşacak şekilde hazırlanmıştır. Hazırlama aşamasında, araştırmanın amacı ve alt problemler göz önüne alınmıştır. Geçerliliği ve güvenirliği için gerekli çalışmalar yapıldıktan sonra uygulamaya geçilmiştir.

Uygulama için hazırlanmış olan görüşme formu, çoğaltılarak Emirdağ İlçe Milli Eğitim Müdürlügüne bağlı olan kurumlarda matematik öğretmeni olarak görev yapan öğretmenlere araştırmacı tarafından uygulanmıştır. $\mathrm{Bu}$ araştırmada ulaşılan 15 öğretmen ile yarı yapılandırılmış görüşme yapılmıştır. Yarı yapılandırılmış görüşme, "araştırmacı tarafindan önceden belirlenen ya da görüşme esnasında ortaya çıkan konulara göre yeni sorularında sorulabildiği görüşme yöntemi” olarak ifade edilmektedir (Güler; Halıcıŏlu \& Taşğın, 2013; Akt. Koç Şanl1, 2018: 72). Araştırmada görüşme yapılacak öğretmenlere sorulacak sorular önceden belirlenmiş ve görüş formuna yazılmıştır. Öğretmenlerle yapılan görüşmeler sırasında öğretmenlerin verdikleri cevaplara göre öğretmenlere yeni sorular sorulmuş ve verdikleri cevap yetersiz ise biraz daha açıklamaları istenmiştir. Elde edilen veriler yorumlanarak, bir nüshası İlçe Milli Eğitim Müdürlüğüne üst yazı ile gönderilmiştir.

\section{Verilerin Analizi}

Nitel araştırmalarda elde edilen verilerin analizi için iki yöntem önerilebilir. Bunlardan ilki betimsel, ikincisi de içerik analizidir.

Betimsel analizde, görüşülen ya da gözlenen bireylerin görüşlerini çarpıcı bir biçimde yansıtmak amacıyla doğrudan alıntılara sık sık yer verilir. Bu tür analizde amaç; elde edilen bulguları düzenlenmiş ve yorumlanmış bir biçimde okuyucuya sunmaktır. Bu amaçla elde edilen veriler, önce sistematik ve açık bir biçimde betimlenir. Daha sonra yapılan bu betimlemeler açıklanır ve yorumlanır. Neden sonuç ilişkileri irdelenir ve birtakım sonuçlara ulaşılır. Ortaya çıkan temaların ilişkilendirilmesi, anlamlandırılması ve ileriye yönelik tahminlerde bulunulması da araştırmacının yapacağı yorumların boyutları arasında yer alabilir (Yıldırım ve Şimşek, 2011: 224).

İlköğretim Matematik Öğretmenlerinin Tam Sayılar Konusunun Modellenmesine İlişkin Öğretmen Görüşlerini tespit etmek amacıyla uygulanan açık uçlu sorulardan oluşan anketten elde edilen veriler, daha önceden belirlenen kavramsal çerçeve veya temalara göre özetlenip ve yorumlandığı için araştırmada "Betimsel Analiz Yöntemi” kullanılmıştır. Araştırma sonucunda elde edilen bulgular; araştırma sorularının ortaya koyduğu temalara göre düzenlenip görüşme ve gözlem süreçlerinde kullanılan sorular ya da boyutlar dikkate alınarak sunulmuştur. 
$\mathrm{Bu}$ noktada elde edilen veriler gerekli tedbirler alınarak araştırmanın geçerliliği ve güvenirliği sağlanarak yorumlanmaya çalışılmıştır.

Araştırma nitel olması nedeniyle, görüşme formundaki soruların geçerliliği ve güvenirliğini tespit etmek için çalışılacak gruptan farklı bir gruba görüşme formu uygulanmıştır. Bu uygulamanın incelenmesi sonucunda görüşme formundaki sorular tekrar düzenlenmiştir.

Araştırmanın kapsam geçerliliğini arttırmak amacıyla anket soruları İlköğretim Matematik Eğitimi Alanında uzman iki öğretim üyesi tarafından incelenerek görüşme formundaki sorular tekrar düzenlenmiştir.

Yarı yapılandırılmış görüşmeler yapılırken daha güvenilir bilgi ve bulgular elde edebilmek için görüşmeler uzun tutulmaya çalışılmıştır. Toplam 15 öğretmenle yapılan görüşmelerde not tutulmuştur. Veri kaybını önlemek adına bazı kısaltmalar kullanıp görüşmelerde alınan notlar, aynı gün yeniden düzenlenmiştir.

Ayrıca görüşmelerde yöneltilen sorulara öğretmenlerimizin bu cevapları verirken ki davranışları da gözlemlenmeye çalışılmıştır.

\section{Etik}

Bu çalışmada çalışmanın hazırlık, veri toplama, analiz ve bilgilerin sunumu olmak üzere tüm aşamalarından bilimsel etik ilke ve kurallarına uygun davrandınıldığını; bu çalışma kapsamında elde edilmeyen tüm veri ve bilgiler için kaynak gösterildiğini ve bu kaynaklara kaynakçada yer verildiğini; kullanılan verilerde herhangi bir değişiklik yapılmadığını, çalışmanın Committee on Publication Ethics (COPE)' in tüm şartlarını ve koşullarını kabul ederek etik görev ve sorumluluklara riayet edildiğini beyan ederiz.

\section{BULGULAR}

Çalışmanın amacı doğrultusunda, Afyonkarahisar ili Emirdağ ilçesinde İlçe Milli Eğitim Müdürlüğü'ne bağlı ortaokullarda görev yapan ilköğretim matematik öğretmenlerine 5 sorudan oluşan bir görüşme formu ile yarı yapılandırılmış görüşmeler gerçekleşmiştir.

Görüşme formunda yer alan 5 soruya verilen cevaplar ayrı başlıklar halinde incelenmiştir.

\section{Soru 1: Tam sayılar konusunu nasıl anlatıyorsunuz? Kısaca açıklayınız.}

Öğretmenlerimize yöneltilen bu soru ile tam sayılar konunun nasıl anlatıldığına dair veri elde etmek amaçlanmıştır. Öğretmenlerimizin cevapları aşağıda vermiştir.

Ö-1 "Sayma pullarlyla modelleme yaparak"

Ö-2 “Tam sayıları tanımladıktan sonra işlemleri sayma pulları ile modelleyerek anlatıyorum. Ayrıca işaretleri teke düşürüp aynı işaretleri toplatıp ters işaretleri çıkartarak konuyu birleştirmeye çalışıyorum. "

Ö-3 “Kar - zarar”, "Borç - alacak”, "sıcaklık sıfırın, üstünde - altında”, “deniz seviyesinden, yüksek alçak” gibi günlük hayattan örneklerle anlatıyorum."

Ö-4 "Somut örnekler vererek anlatıyorum"

Ö-5 “Öncelikle günlük hayattan örnekler vererek; tam sayı kavramını, pozitif ve negatif sayıyı öğrencilerin kavramasını sağllyorum. Daha sonra konuya giriş yapıyorum”

Ö-6 "Somutlaştırarak ve güncel hayatla bağlantılar kurarak ögrencilerin zihninde kalıcı öğrenmeler yaratmaya çalışlyorum"

Ö-7 “Tam sayılar konusunu genellikle etkinlik yaparak anlatmaya çalışıyorum. Kitaptaki etkinleri sınıfin katılanlarıyla yaptırmaya çalışıyorum. Sinıfi birkaç guruba ayırıp her bir guruba farklı etkinlik yaptırlyorum."

Ö-8 "Tam sayllarda; toplama ve çıkarma işlemini anlatırken önce sayı doğrusu üzerinde sonra da sayma pullarıyla modelleyerek mantığını anlatmaya çalışıyorum. Mutlak değer konusunda ise mutlak değeri çamaşır 
makinesi gibi düşünmelerini istiyorum. + ları temiz, - leri kirli olarak düşünüyorlar. Sonuç her zaman temiz olur diye buluyorlar. "Çarpma ve bölmeyi” ise dost düşman mantığılla çözüyorlar."

Ö-9 "Öncelikle $a-b$ ve $a+(-b)$ işlemlerini karşılaştırarak işlemin aynı olduğunu ögrenciye göstererek farkındalık kazanmasını sağllyorum, işlemleri yaparken "+ cebimdeki para”, "- borç” olarak modelleyerek alıştırmalar yapıyorum. İşlem çıkarma işlemi ise önce toplama işlemine çevirip daha sonra borç ve cebimdeki para olarak hesaplamalarını sağllyorum. '”

Ö-10 "Düz anlatım ve soru-cevap şeklinde konuyu anlatıyorum."

Ö-11 “Tam sayılar konusuna giriş yapmadan önce sayma sayılarını ve doğal sayıları hatırlatıyorum. Daha sonra ihtiyaçtan doğduğunu fark ettirerek tam sayllar konusuna giriş yapıyorum. Tam sayllarda toplama ve çıkarma işlemleri için, içerisinde işlem gerektiren adımlar olan yönergeli bir oyun oynatıyorum."

Ö-12 "Toplama ve çıkarma işlemlerini modelleyerek, çarpma ve bölme işlemlerini modelleme kullanmadan anlatiyorum."

Ö-13 “ilk olarak (-) ve (+) nın nerelerde kullanıldı ̆̆ bilgilerini verip, farkı kavrattırıyorum. Sonra; toplama - çıkarma durumlarında yan yana geldiklerinde ortak çıkacak sonuçları bulduruyorum, Dost - Düşman ilişkisine vererek kalıcılı̆̆ sağlamaya çalışıyorum”

Ö-14 “Tam sayı ismini söylemeden; "Hayatta negatif sayllara neden ihtiyaç duyulmuştur?" Sorusunun cevabını ögrencilere buldurmaya çalışmakla derse başlıyorum. Doğal sayılar kümesinden hareketle tam sayılara geçiş yapıyorum, tam sayılar ögrencilerin akıllarında olmaya başladıktan sonra gündelik hayat örneklerini vermeye başllyoruz, sonrasında bu örnekle işlem içeren örneklerle devam ediyoruz. Öğrencilerde tam sayılar algısı oluştuktan sonra ders kitabına geçiyoruz ve ders kitabılla beraber tam sayıları modelliyoruz"

Ö-15 “Tam sayılar konusunun anlatımında olabildiğince günlük hayattan örnekler kullanıyorum. Konuya ilk geçişte; alacak, verecek, borç, hava sıcaklı̆̆l, binalarda kat numaraları gibi, günlük hayattan toplama ve çıkarma işleminde farkl, çarpma ve bölme işleminde farklı modellemeler kullanıyorum."

Öğretmenlerimizin cevapları doğrultusunda aşağıdaki tablo oluşturulmuştur.

\section{Tablo 1.}

Tam Sayılar Konusunun Anlatımında Kullanılan Yöntemler

\begin{tabular}{lll}
\hline Tam Sayılar Konusunun Anlatımı & Frekans & Yüzde \\
\hline Model-Bağlam kullanarak anlatıyor & 15 & $\% 100$ \\
\hline Toplam & $\mathbf{1 5}$ & $\% 100$ \\
\hline
\end{tabular}

Araştırmaya katılan öğretmenlerimizin \%100'ünün, yani tamamının konuyu model veya bağlamları kullanarak öğrencilere aktardıkları görülmüştür.

\section{Soru 2: Tam sayılar konusunun öğretiminde ne tür modellerden-bağlamlardan yararlanıyorsunuz?}

Ankete katılan öğretmenlerimizin çoğunluğu 1. Soruda tam sayılar konusunu modelleme yaparak anlattıklarını ifade etmişlerdir. Buradan hareketle 2.soruda tam sayılar konusunu anlatırken hangi modellerden ve bağlamlardan yararlandıkları sorulmaktadır. Bu soruya öğretmenlerimiz aşağıdaki cevapları vermişlerdir.

Ö-1 "Sayma pullarından yararlaniyoruz"

Ö-2 "Sayma pulları ile modelleme, sayı doğrusunda gösterme veya alacak borç ilişkisi kurma."

$\ddot{\boldsymbol{O}}$-3 “internetten örnekler ve sayma pullart."

Ö-4 "Sayma pullarl yöntemini kullanıyorum."

Ö-5 “Sayı doğrusu, termometre, bina maketi, eşit kollu terazi, vb. modellemeler kullanıyorum." 
Ö-6 "Sayı doğrusu, termometre, bina maketi, eşit kollu terazi, vb. modellemelerden yararlanmaya çalışlyorum."

Ö-7 “Genellikle sayma pullart ile modelleme yapıyorum. Sayı doğrusu modeli kullanıyorum.”

Ö-8 "Sayma pulları yardımıyla."

Ö-9 "Modelleme olarak; işlem toplama olduğu sürece borç ve cebimdeki para ile ögrrenciye işlem yaptırlyorum, çıkarma işleminde ise önce toplamaya çevirip daha sonra aynı işlem üzerinden işlem yapmaların sağllyorum, sözlü ifadelerle ve görsel çizimlerle de destekliyorum."

Ö-10 "Negatif ve pozitif tam sayı kartlarından yararlanıyorum."

Ö-11 "Gerçek yaşam olaylarından yararlanıyorum. Negatif sayılar için sarı fon kartonundan kesilmiş kağıtlardan, pozitif sayılar için mor fon kartonundan kesilmiş kağıtlardan yararlanıyorum."

Ö-12 "Sayma pullart."

Ö-13 “( - ) ve (+) birim kodlarinı kullaniyorum.”

Ö-14 ’Sayma pulları, sayı doğrusu, termometre, deniz seviyesi, alacak - borç, kar - zarar."

Ö-15 "Sayma pulları çizerek anlatıyorum."

Öğretmenlerimizin verdikleri cevaplar doğrultusunda aşağıdaki tablo oluşturulmuştur.

Tablo 2.

Tam Sayıların Anlatımında Kullanılan Model ve Bă̆lamlar

\begin{tabular}{lll}
\hline Kullanılan Modellemeler & Frekans & Yüzde \\
\hline Sayma Pulları(M) & 12 & $\% 80$ \\
Sayı Doğrusu(M) & 5 & $\% 33$ \\
Alacak - borç(B) & 3 & $\% 20$ \\
Kar - Zarar(B) & 1 & $\% 6$ \\
Termometre(B) & 3 & $\% 20$ \\
Bina Maketi(B) & 2 & $\% 13$ \\
Eşit Kollu Terazi(B) & 2 & $\% 13$ \\
Deniz Seviyesi(B) & 1 & $\% 6$ \\
\hline Toplam & 15 & $\% 100$ \\
\hline
\end{tabular}

Öğretmenlerimizin “Tam sayılar konusunun öğretiminde ne tür modellemelerden yararlanıyorsunuz?” sorusuna verdikleri cevaplardan; öğretmenlerin \% 80'inin sayma pullarını kullandığı görülmektedir. Sayma pullarından sonra öğretmenlerin \% 33'ünün sayı doğrusu kullandığı tablodan görülmektedir. Ayrıca verilen cevaplar incelendiğinde, öğretmenlerin tek bir model kullanmadıkları da fark edilmektedir. Yani öğretmenlerin verdikleri cevaplardan konuyu anlatmak için birden fazla model ve bağlam kullandıkları anlaşılmaktadır. Öğretmenlerin \%20'si alacak-borç ve termometre bağlamlarını, \% 13'ü bina maketi ve eşit kollu terazi bağlamlarını, \%6'sı kar-zarar ve deniz seviyesi bağlamlarını kullandıkları görülmektedir. Konuyu daha çok model kullanarak anlatmaktadırlar.

\section{Soru 3 : Tam sayılar konusunun öğretiminde modelleme yapılmasının yararları nelerdir?}

Görüşme yapılan öğretmenlerimize modellemenin faydaları sorulduğunda aşağıdaki cevaplar elde edilmiştir.

Ö-1 "Görsel açıdan daha iyi anlaşılmaktadır, özellikle tam sayılarda çıkarma işlemi yapılırken modelleme yapılarak daha iyi anlaşılır."

Ö-2 "Konunun anlaşılması açısından öncelikle görsel ögrencilerde daha etkili ve akılda kalıcı olduğunu düşünüyorum."

Ö-3 "Görsel olduğu için daha iyi anllyorlar." 
Ö-4 "Somut olduğu için, görerek - yaparak öğrenmek uzun süre kalıcı öğrenme yaşıyor."

Ö-5 "Öğrencilerin konuyu daha somut biçimde ögrendiklerinden modellemenin faydası oluyor, özellikle negatif say kavramında modelleme yapmak faydalı oluyor."

Ö-6 “Öğrencilerin konuyu daha somut biçimde algılamaları ile kalıcı şemalar oluşturmaları sağlanıyor."

Ö-7 “Matematik soyut bir kavram olduğu için ögrrencilerin büyük bir çoğunluğu ögrenme sürecinde zorluk çekiyor. Modellemeler yaparak konuyu somutlaştırıp öğrencilerin konuyu daha rahat anlamalarını să̆lamış oluyor."

Ö-8 "Soyut bir konuyu somutlaştırmış oluyoruz."

Ö-9 “Gündelik hayattan örnekler vermek ve bunların yaşama yakın olması kalıcıllğg arttırıyor. Uzun süreli ögrenmelerde etkili bir yöntemdir, yaşama yakınlık.”

Ö-10 "Öğrencilerin mantı̆̆ını kullanarak konuyu daha iyi anlamalarını să̆lar."

Ö-11 "Konunun somutlaştırllarak akılda kalıcı hale gelmesine yardımcı oluyor."

Ö-12 "Kalıcı olmasını sağllyor. Somut hale getirilmesinden dolayı öğrenmeyi kolaylaştırır."

Ö-13 “Çocuklar; (-) ve (+) birbirini sıfırladı̆̆ını yani ortadan kaldırdığını daha rahat görüyor."

Ö-14 "Matematikte modellemeler, matematiğin günlük hayatta kullanışlılı̆̆ını artırdıkça faydalı olduğunu düşünüyorum. Sadece cebirsel olarak işlem yapmak çok daha az öğrenciye hitap ediyor ve kalıcılı̆̆ı daha az. Modelleme ile konunun ulaştı̆̆ öğrenci sayısı artıyor ve kalıcılık da daha fazla. Tam sayıları düşündügümüzde sadece bir yönteme bağl kalarak anlatılmaktan ziyade birkaç yöntem ile modelleme yapılırsa ögrenme oranının daha fazla olacă̆ını düşünüyorum.”

Ö-15 "Modelleme kullanıldı̆̆ında daha anlaşılır ve somutlaştırılmış bir ders anlatımı oluyor."

Elde edilen veriler doğrultusunda modellemenin faydalarının daha net anlaşılması açısından aşağıdaki tablo oluşturulmuştur.

Tablo 3.

Modellemenin Faydalart

\begin{tabular}{lll}
\hline Modellemenin Faydaları & Frekans & Yüzde \\
\hline Görselleştirme & 2 & $\% 13$ \\
Kalıcı hale getirme & 7 & $\% 46$ \\
Somutlaştırma & 9 & $\% 60$ \\
Daha iyi anlama & 5 & $\% 33$ \\
\hline Toplam & 15 & $\% 100$ \\
\hline
\end{tabular}

Öğretmenlerimizin verdiği cevaplar incelendiğinde; öğretmenlerin \%60’ı modelleme yapılmasının konuyu somutlaştırdığg görüşündedir. Öğretmenlerin \%46’sı modelleme yapılmasının konuyu kalıcı hale getirdiğini, \%33’ü konunun daha iyi anlaşıldığını, \%13'ü ise konuyu görselleştirdiğini ifade etmektedir.

Araştırmada bu soru ile elde edilen bilgiler doğrultusunda öğretmenlerimizin çoğunluğu modellerin ve bağlamların konuyu somutlaştırmada faydalı olduğunu düşünmektedir. Öğretmenlerimizin kayda değer bir kısmı da modelleme yapılarak anlatılan konunun öğrencilerin zihninde daha kalıcı hale geldiğini ifade etmektedirler.

Diğer yandan az sayıda öğretmenlerimiz de model kullanımının ve bağlamlardan yararlanmanın konuyu görselleştirdiğini dolayısıyla konunun somutlaştırıldığı görüşüne sahiptirler.

Soru 4 : Tam sayıları anlatırken uyguladığınız modellemenin eksik yönleri olduğunu düşünüyor musunuz? Düşünüyorsanız, bu eksiklikler nelerdir? 
Öğretmenlerimizin bu soruya verdiği cevaplar aşă̆ıdaki gibidir:

Ö-1 "Hayır."

Ö-2 "Pullar ile modellemede; birinci sayı negatif iken çarpmanın modellenmesi, ikinci sayı negatif iken de bölmenin modellenmesi sıkıntılı. Sayı doğrusunda gösterimde ise yine birinci sayı negatif iken modelleme sikintıll."

Ö-3 "Evet, daha çok günlük hayattan örnekler verilmelidir."

Ö-4 "Eksik yönleri olduğunu düşünmüyorum."

Ö-5 "Modelleme yaparken çocuklara sayma pullarını öğretmekte bir problem çıkmıyor. Ancak özellikle çıkarma işlemi yaparken öğrenciler işlemi yapamıyor. Günlük hayattan "borç - alacak” olarak verilen örnekler çıkarmayı kavratmada daha etkili oluyor."

Ö-6 “Modelleme tam anlamıyla konuyu ifade etmiyor. Ancak henüz soyut işlemler dönemine girmeyen ögrencilerin anlamasını kolaylaştırmakla beraber zaman zaman yanlış algılamalara neden oluyor.”

Ö-7 Mutlaka dört dörtlük olmuyor. Bazen çocuklar gösterdiğimiz modellemeyi tam olarak kavrayamayabiliyor. Bunun için çocukların o modellemeyi kendileri veya grup halinde etkinlik olarak yapmaları gerekiyor. Bir de derste zorlandıkları yerlerde materyal kullanımı biraz daha bu güçlükleri aşmada iş yarlyor."

Ö-8 "Sayma pulları kullanırken bazı ögrenciler somutlaştırmada zorluk çekiyorlar. Çarpma işleminin işareti konusunda, "neden öyle olduğunu?” anlamıyorlar. Dolayısıyla biraz da ezber yapmış oluyorlar."

Ö-9 “Düşünmüyorum.”

Ö-10 "Modellemenin eksik yönleri olduğunu düşünmüyorum."

Ö-11 “Tam sayılar konusunda, eşit kollu teraziyi kullanmak daha yararlı olacaktır. Fakat materyal eksikliği nedeniyle eldekiler yetmiyor. Öğrencilere eşitlik kavramını kavratamıyorum. O nedenle de büyük-küçük kavramı çok oturmuyor."

Ö-12 "Toplama ve çıkarma işlemlerinin modellenmesinde sıkıntı yaşanmıyor. Yalnı çarpma ve bölme işlemleri modellenemiyor(Kısıtlı). Modellenebilen ise kalıcı olmuyor. Anlaşılması da zor."

Ö-13 "Düşünmüyorum."

Ö-14 "Sayma pulları ile modelleme yönteminde; negatif sayıların bölümü, negatif sayıların çarpımı gibi işlemlerde anlamayı kolaylaştırmaktan çok zorlaştırdı̆̆ını düşünüyorum. Bu yüzden modelleme yapmak için modelleme yapmaktan çok, faydalı olup olmadığına bakılarak tam sayıları kolaylaştırdığı sürece kullanılmalı, akıl karışıklığ yapacă̆ yerlerde ise diğer yöntemler ile modellenmesi gerektiğini düşünüyorum. Matematiğin epistemolojisi gereği her konuda modelleme yapılarak matematĭ̆in kolaylaştırılabileceğini pek düşünmüyorum. Bazen cebirsel olarak anlatılması kanaatimce daha uygun."

Ö-15 “Düşünmüyorum. Çünkü ögrenciler bu yöntemlerle konuyu anllyor ve soruları çözebiliyorlar.”

Öğretmenlerimizce bu soruya verilen cevaplar aşağıdaki tabloda daha açık ve bütüncül bir şekilde ifade edilmiştir.

\section{Tablo 4.}

Modellemenin Eksik Yönleri

\begin{tabular}{lll}
\hline Modellemenin Eksik Yönleri & Frekans & Yüzde \\
\hline Düşünmüyor & 6 & $\% 40$ \\
Konuyu tam ifade etmiyor & 2 & $\% 13$ \\
Bazı konularda yetersiz & 6 & $\% 40$ \\
\hline
\end{tabular}




\begin{tabular}{lll}
\hline Günlük hayattan uzak & 1 & $\% 7$ \\
\hline Toplam & 15 & $\% 100$ \\
\hline
\end{tabular}

Tabloya bakıldığında, öğretmenlerin \%40’ı kullandıkları modellerin ve bağlamların eksik yönleri olduğunu düşünmemektedir. Aynı şekilde yine öğretmenlerimizin \% 40'1, konunun bazı alt konularının modellenmesinde kullanılagelen modellerin ve bağlamların yetersiz kaldığını düşünmektedir. Öğretmenlerin \%13'ü ise kullandıkları modelleme yöntemlerinin konuyu tam olarak temsil etmediğini düşünmektedir.

Mevcut modellerin ve bağlamların bazı konuların ifade edilmesinde yetersiz olduğunu, yani anlatılmak isteneni tam olarak temsil etmediğini düşünmektedir. Öğretmenler, tam sayılarda özellikle çarpma ve bölme işlemlerinin modellenmesinin zor olduğunu ifade etmektedirler.

Öğretmenlerimizden birisi (Ö-6) modellerin bazen yanlış algılamalara neden olduğunu belirtirken, bir diğer öğretmenimiz (Ö-14) ise modellerin her zaman kullanışlı olmadığını, bazen konunun cebirsel olarak anlatımının daha uygun olacağını ifade etmektedir.

Soru 5: Tam sayılar konusunu anlatırken yararlandığınız modellerin ve bağlamların dışında tam sayılarda kullanılabilecek farklı modelleme yöntemleri ilgili bilgi sahibi misiniz? Ĕger farklı modelleme yöntemleri hakkında bilgi sahibi iseniz, bu modeller hakkında bilgi verir misiniz?

Bu soru, öğretmenlerimizce kullanılan modellerin ve bağlamların çeşitliliği hakkında bilgi toplamak ve bilgi sahibi olmak amacıyla sorulmuştur. Öğretmenlerimizin cevapları aşağıdaki gibidir.

Ö-1 "Farkl modellemeler hakkında bilgi sahibi değilim."

Ö-2 "Bunların dişında farklı bir modelleme kullanmiyorum."

Ö-3 "Hayır."

Ö-4 “Öğrencilere materyal olarak sayı doğrusu çizdirilebilir. Adım atma yöntemi kullanılabilir.”

Ö-5 "Yok."

Ö-6 "Yok."

Ö-7 “Yok."

Ö-8 "Bilgi sahibi dĕgilim."

Ö-9 “Benim anlattı̆̆ım yöntemle öğrencinin kafası karışmadı̆̆ ve anladı̆̆ için başka yöntem düşünme ihtiyact duymuyorum."

Ö-10 “Yok."

Ö-11 "Dört kollu terazi ile ilgili okuduğum modellemeye göre bu yöntem oldukça etkili görünüyor. Özellikle negatif ve pozitif tam sayıların karşılaştırılmasında oldukça etkili olduğunu biliyorum."

Ö-12 "Yok."

Ö-13 "Bilgi sahibi değilim."

Ö-14 "Tam sayıların modellenmesi konusunda belirttiğim modellemeler dışında şu an için aklıma gelen ve kullanmadı̆̆ım bir modelleme yok. Tam sayılar için yaklaşık 4-5 modelleme yaparak konuyu anlatmaya çalışıyorum. Bunların kullanılması bile zaman açısından sıkıntılara sebebiyet veriyor. Bir derste abartılı bir şekilde modelleme kullanılmasına taraftar değilim. Modellemenin konunun anlaşılması kısmında etkili olduğunu düşünüyorum. Sinav sistemimizde kullanılan test sorulart için sadece modelleme ile yetinmek bana kalırsa yetersiz olabilir."

Ö-15 “Ders kitaplarındaki etkinliklerde verilen örnekleri ve oyunları kullanıyorum."

Öğretmenlerimiz tarafından son soruya verilen cevaplar aşağıdaki tabloda daha açık ve bütüncül bir şekilde 
ifade edilmiştir.

\section{Tablo 5.}

Ögretmenlerin Farklı Modellemeler Hakkındaki Bilgisi

\begin{tabular}{|c|c|c|}
\hline Farklı Modellemeler & Frekans & Yüzde \\
\hline Bilgi sahibi değil & 12 & $\% 80.0$ \\
\hline Sayı doğrusu & 1 & $\% \quad 6 . \overline{6}$ \\
\hline Dört kollu terazi & 1 & $6 . \overline{6}$ \\
\hline Ders kitabındaki etkinlik ve oyunlar & 1 & $6 . \overline{6}$ \\
\hline Toplam & 15 & $\% 100$ \\
\hline
\end{tabular}

Beşinci soruya verilen cevaplara ilişkin tablo incelendiğinde; öğretmenlerimizin \% 80'i konuyla ilgili bilgi sahibi olmadıklarını belirtmişlerdir. Ö-4 sayı doğrusunun materyal olarak çizdirilip adım atma yöntemini, Ö11 dört kollu teraziyi, Ö-15 ise ders kitabındaki etkinlikleri ve oyunları farklı birer model olarak sunmuştur.

Bu soruya verilen cevaplardan öğretmenlerimizin farklı modelleme yöntemleri hakkında pek fazla bilgi sahibi olmadıkları ortaya çıkmıştır. Yapılan görüşmelerden de öğretmenlerimizin farklı modeller hakkında araştırma yapmadıkları anlaşılmaktadır.

Görüşme ile ilgili genel bir sonuç ve yorum çıkarmak için yapılan görüşmenin bütününe bakmamız gerekmektedir.

Görüşmelerden elde edilen verilerin tamamı incelendiğinde öğretmenlerin tamamının tam sayı konusunu model ve bağlam kullanarak işledikleri görülmektedir. Öğretmenlerimizin modelleme yaparken en çok kullandıkları model sayma pullarıdır. Ayrıca sayma pullarının yanı sıra; sayı doğrusu, alacak-borç, kar-zarar, termometre, deniz seviyesi, bina maketi gibi model ve bağlamlarla konuyu günlük hayata uygun hale getirmeye çalıştırmaktadırlar.

Modellemenin konuyu somutlaştırdığ1 ve anlatımı da görsel olarak desteklendiği için kalıcılığ1 sağladığ1 görüşündedirler. Bazen model ve bağlamların konuyu tam anlamıyla ifade edemediğini ayrıca belirtmişlerdir. Farklı model ve bağlamlar hakkında pek bilgi sahibi olmadıklarını da beyan etmişlerdir.

Yapılan görüşmeler sonunda öğretmenlerimizin konuyu anlatmak için kullanılacak modeller hakkındaki bilgilerinin sınırlı olduğu görülmektedir. Öğretmenlerimizin bu konuda kendilerini geliştirmek için bir çaba harcamadıkları izlenimine ulaşılmıştır. Bunun en önemli sebeplerinden birisi olarak, konuya ayrılan sürenin yetersiz olması gösterilmektedir. Öğretmenlerimizin çoğu kısa sürede istenilen kazanımın modelleme yaparak öğrenciye aktarılmasının mümkün olmayacağı fikrine sahiptir. Dolayısıyla öğretmenlerimiz yeni modelleme yöntemleri araştırıp dersi daha etkin ve eğlenceli hale getirmekten ziyade, daha hızlı ve doğru soru çözme teknikleri araştırmaktadırlar. Bu şekilde işlenen bir matematik dersinde üst düzey düşünme becerilere sahip öğrenciler konu ile ilgili hedeflenen kazanıma sahip olurken, diğer öğrenciler istenilen kazanıma ulaşamamaktadırlar. Dolayısıyla oluşan bu başarısızlıktan dolayı öğrencide matematiğe karşı, matematik dersinin başarılamayacak kadar zor bir ders olduğu kanaati ve ön yargısı oluşmaktadır

\section{TARTIŞMA / SONUÇ / ÖNERİ}

$\mathrm{Bu}$ araştırma, tam sayılar konusunun modellenmesine ilişkin öğretmen görüşlerini elde etmek amacıyla yapılmıştır. Bu nedenle, Afyonkarahisar ili Emirdağ İlçe Milli Eğitim Müdürlüğü’ne bağlı kurumlarda görev yapan matematik öğretmenlerine önceden hazırlanan ve beş tane açı uçlu sorudan oluşan yarı yapılandırılmış görüşme uygulanmıştır. Bu araştırmanın çalışma grubu; aynı bölgede görev yapan Ortaokul Matematik öğretmenlerinden oluşmaktadır. Bu bağlamda; Afyonkarahisar İli, Emirdă̆ İlçe Milli Eğitim Müdürlüğüne bağlı eğitim kurumlarında görev yapan ortaokul matematik öğretmenleri araştırmanın evrenini oluşturmaktadır.

$\mathrm{Bu}$ araştırmada elde edilen bulgulardan hareketle, bu bulgular doğrultusunda aşağıda sonuçlar çıkartılmıştır. 
1) Araştırmaya katılan öğretmenlerimizin tam sayılar konusunu daha çok modelleyerek anlattı̆̆ görüşüne varllmıştır.

$\mathrm{Bu}$ sonuç; Zengin (2014)'in, tam sayılar konusunun tarihsel gelişimi ve günümüze kadar olan sürecin incelenmesinde ortaokul matematik öğretmenlerinin görüşlerini incelediği çalışmasındaki, "öğretmenlerin tam sayılar konusunda modellenmeden yararlandıkları" sonucu ile örtüşmektedir.

2) Konunun modellenerek anlatılmasında öğretmenlerimizin en çok sayma pullarını kullandĭ̆ görülmüşü̈r. Ayrıca sayma pullarının yanı sıra konuyu günlük hayattan örneklerle anlattıklarını belirtmişlerdir. Bunlara örnek olarak; kar-zarar, alacak-borç, termometre gibi modellemeler verilmiştir.

Hayes 1996'da yaptığı "Negatif Sayılar Kavramının ve İşlemlerinin Öğretilmesi” başlıklı çalışmasında öğrencilere negatif sayıları ve negatif sayılarla işlemleri öğretmede en çok kullanılan yöntemlerin etkililiği araştırılmıştır. Bu en çok kullanılan yöntemi $+1,-1$ ve 0 yazan materyal olarak tanımlamıştır ki bu materyalin sayma pulu olduğu anlaşılmaktadır.

3) Kullanılan modellemelerin görsel olarak öğrencinin ilgisini çektiği, konuyu somutlaştırıp daha anlaşılır ve kalıcı hale getirdiği sonucuna varılmıştır.

Araştırmada elde edilen bu sonuç; Çetin (2017) tarafından "Çoklu Temsil Destekli Tasarlanan Manipulatiflerin Tam Sayı Öğretiminde Öğrenci Başarısına Etkisi” isimli araştırmasında ulaşılan, "uygulanan çoklu temsil destekli manipulatifler ile tasarlanmış öğretimin, geleneksel öğretime göre daha etkili olduğu" sonucu ile örtüşmektedir.

Ayrıca Bahadır ve Özdemir (2013) yaptıkları çalışmada; “canlandırma yönteminin kullanıldığı deney grubuna düz anlatımın kullanıldı̆̆ı, kontrol grubuna göre tam sayılarla işlem yapma ve hatırlamada daha yüksek başarıya sahip oldukları" sonucunu araştırmamızın sonuçları da destekler niteliktedir.

Araştırmamızı destekleyen başka bir çalışmada, Hayes (1996)'in negatif sayılarla ilgili yaptığı bir araştırmadır. Bu araştırmada negatif sayılar; deney grubuna model kullanılarak anlatılırken kontrol grubuna düz anlatım yöntemiyle verilmemiş ve sonuçta, deney grubundaki orta düzey öğrencilerin başarılarında bir artış görülmektedir. Araştırmamızda modellerin faydaları hakkında elde ettiğimiz sonuç, bu sonucu desteklemektedir.

Benzer şekilde Mc Corkle'de (2001) hazırladığı tezinde; yedinci sınıf öğrencilerine pozitif ve negatif tamsayıların farklı metotlar kullanılarak nasıl toplama ve çıkarma yapacakları öğretilmiştir. Deney grubu; termometre ölçüsünün kullanıldığı "sıcak ve soğuk küpleri” kullanarak ilişkisel yaklaşımla öğrenim görürken, kontrol grubu kitap kurallarının ezberlenmesini gerektiren kurallı yaklaşımla öğrenim görmüştür. Araştırma sonucunda; deney grubundaki öğrencilerin testlerden daha yüksek sonuç aldığg ve bilgileri hatırlamada daha iyi olduğu görülmüştür. Bu sonuç ile araştırmamızda modellerin faydaları ile ilgili elde edilen sonuç aynı şeyi ifade etmekte yani örtüşmektedir.

Hackbarth'in (2000) araştırmasında amaç; yedinci sınıflara öğretilen tam sayılarla toplama ve çıkarma yöntemlerinin öğrencilerin matematik başarısı ve hatırlama düzeylerini nasıl etkilediğini belirlemek olmuştur. $\mathrm{Bu}$ araştırmada farklı metotların kullanıldı̆̆ 1 üç farklı grup oluşturulmuştur. Araştırmanın sonucunda; tam sayılarda toplama ve çıkarma öğretiminin, kullanılan metotlara dayalı olarak ayrıştığı, ancak bu üç grup arasında hiçbir istatistiksel farklılığın bulunmadığı ortaya çıkmıştır. Bu sonuçla araştırmamızın sonucu farkl11ı göstermektedir.

4) Kullanilan modellemelerin tam sayılar konusunda anlatılmak isteneni tam anlamıyla temsil etmediği, bazı noktalarda yetersiz kaldı̆̆ vurgulanmıştır.

Cankoy (2005) araştırmasında öğretmen adaylarının iki negatif tam sayının modellerle ifade etmekte zorlandıkları sonucu ile bu araştırmadaki modellerin konu ifade etmekte yetersiz kalması ve konuyu tam ifade 
edememesi sonuçları birbirini destekler niteliktedir.

Ayrıca Hayes ve Stacey'de (1999) tam sayılarda kullanılan modellerden sayma pulları ile sayı doğrusunun karşılaştırılmasıyla ilgili yaptıkları araştırmanın sonucu ile araştırmamızın sonucu örtüşmektedir. Hayes ve Stacey'nin (1999) araştırmalarına göre toplama işleminin sayma pulları ve sayı doğrusunda modellenmesinde herhangi bir sorun yaşanmazken çıkarma işleminin modellenmesinde işlem ile sayının işaretinin karıştırıldığı görülmektedir. Bu çalışmada elde edilen sonuç araştırmamızın modellerin bazı noktalarda yetersiz kaldığ sonucunu destekler mahiyettedir.

Bu sonuçtan hareketle, tam sayıları tam anlamıyla ifade etmeyen bir modelin eksiklikleri ve bu eksikliklerin giderilmesiyle ilgili bir araştırma yapılabilir.

5) Öğretmenlerimizin belirttikleri modellemeler dışında farklı modellemeler hakkında bilgi sahibi olmadıklarl görülmüştür.

\section{KAYNAKÇA}

Bahadır, E. \& Özdemir A. Ş. (2013). Tam sayılar konusunun canlandırma tekniği ile öğretiminin öğrenci başarısına ve hatırlama düzeyine etkisi. International Journal Social Science Research, 2(2), 114-136.

Bozkurt, A. \& Polat, M. (2011). Sayma pullarıyla modellemenin tam sayılar konusunu öğrenmeye etkisi üzerinde öğretmen görüşleri. Gazi Üniversitesi Sosyal Bilimler Dergisi, 10(2), 787-801.

Cankoy, O. (2005). Negatif ve pozitif işaretli sayıların çarpımının öğretimine öğretmen adaylarının önerdiği yöntemlerdeki benzetimler. Hacettepe Üniversitesi Ĕ̌itim Fakültesi Dergisi, 29, 63-68.

Çetin, H. (2017). Çoklu temsil destekli tasarlanan manipulatiflerin "tam sayı" öğretiminde öğrenci başarısına etkisi. Uluslararası Eğitim Bilimleri Dergisi, 11, 55-69.

Çiltaş, A. \& Işık, A. (2013). Matematiksel modelleme yoluyla öğretimin ilköğretim matematik öğretmeni adaylarının modelleme becerileri üzerine etkisi. Kuram ve Uygulamada Eğitim Bilimleri, 13(2), 11771194.

Dündar, H. \& Akyol, H. (2014). Okuma ve anlama problemlerinin tespiti ve giderilmesine ilişkin örnek olay çalışması. Eğitim ve Bilim, 39(171), 361-377.

Ertuğrul, G. (2009). Yeni ilkögretim matematik dersi 6. sınıf ögretim programında yer alan tam sayılarla ilgili etkinliklerin ögrenci başarısına etkisi. Yüksek Lisans Tezi, Selçuk Üniversitesi, Fen Bilimleri Enstitüsü, Konya.

Güneş, G. (2010). İlköğretim ikinci kademe matematik öğretiminde oyun ve etkinliklerin kullanımına ilişkin ögretmen görüşleri (Kars ili örneği). Yüksek Lisans Tezi, Kafkas Üniversitesi, Sosyal Bilimler Enstitüsü, Kars.

Hackbarth, M. C. (2000). A comparison of the effectiveness in teaching the addition and subtraction of integers using manipulatives versus rules to seventh grade students. Master Thesis, California State University Domingues Hills, USA.

Hayes, B. (1996). Teaching for understanding of negative concepts and operations. Master Thesis, University of Melbourne, Depermant of Science and Mathematics Education, Australia. www.aare.edu.au/data/publication/1996/hayeb96054.pdf

Hayes, B. \& Stacey, K. (1999). Teaching negative numbers using integer tiles. In 22nd Annual Conferance of the Mathematic Education Research Group of Australia. https://www.researchgate.net/publication/238721666

Karasar, N. (2014). Bilimsel araştırma yöntemi: kavramlar-ilkeler-teknikler. Ankara: Nobel Yayın Dağıtım.

Koç Şanlı, K. (2018). Ortaokul matematik ögretmenlerinin tam saylların ögretim sürecinde model kullanma becerileri ve model kullanımına yönelik görüşleri. Yüksek Lisans Tezi, Erciyes Üniversitesi, Eğitim Bilimleri Enstitüsü, Kayseri.

.Köroğlu, H. \& Yeşildere, S. (2004). İlköğretim yedinci sınıf matematik dersi tamsayılar ünitesinde çoklu zeka teorisi tabanlı öğretimin öğrenci başarısına etkisi. Gazi Üniversitesi Eğitim Fakültesi Dergisi, 24(2), 25-41.

Mc Corkle, K. L. (2001). Relational and instrumental learning when teaching the addition and subtraction of positive and negative integers. California StateUniversity, Dominguez Hills, CA. 
Olkun, S. \& Toluk, Z. (2003). İlköğretimde etkinlik temelli matematik öğretimi. Ankara: Anı Yayınc1lık.

Van de Walle, J. A. (2018). İlkokul ve ortaokul matematiği gelişimsel yaklaşımla öğretim. Ankara: Nobel Akademik Yayınc1l1k.

Yıldırım, A. \& Şimşek, H. (2011). Sosyal bilimlerde nitel araştırma yöntemleri. Ankara: Seçkin Yayıncılık.

Zengin, Ş. (2014). Tam sayıların tarihçesi ve tam sayılar konusunun öğretimine ilişkin öğretmen görüşleri. Yüksek Lisans Tezi, Fırat Üniversitesi, Eğitim Bilimleri Enstitüsü, Elazı̆̆.

\section{EXTENDED ABSTRACT}

Research Purpose: The aim of this study is to use teachers 'views on the modeling of the subject of integers, to investigate which models are used by teachers in explaining four operations with integers and integers, and how effective these models are in students' comprehension of the subject.

Research Questions: Which models are used to explain the subject of integers? What are the benefits of using a model to explain the subject of integers? What are the drawbacks of using a model to explain the subject of integers? Are there different models that can be used to explain the issue of integers?

Literature Review: After the research question was created, a literature search was conducted with integers and modeling keywords. In the study, it was revealed that learning mathematics does not only provide information to the individual, but also gives the individual multi-directional thinking skill. In addition, it enables the individual to think faster and in a logical framework. Considering the benefits of learning mathematics to the individual, mathematics education and teaching is important. The subject of integers starts to be explained in the 6th grade. This period is the period when students are between the ages of 11-14. In other words, it is the period when they begin to pass the period of abstract operations. In addition, it is seen that primary school years coincide with a period in which children develop very rapidly in terms of physical and mental aspects. This change in the development of children in primary education mathematics; it makes it necessary to be meticulously organized in terms of content, method, and equipment. The fact that mathematics teaching and the handling of mathematical concepts lack content and concrete experience makes it difficult to learn. For this, the mathematics program was renewed in 2005. The aim of the mathematics program, which was rearranged in 2005; It is to give the person the mathematical knowledge and skills required by daily life, to teach him to solve problems and to give him a way of thinking that handles events in a problem approach. Profit-loss, budget preparation, debt-credit, thermometer, elevator etc. examples are emphasized. As can be understood from here, it was emphasized that the student should be active in learning. In the renewed Mathematics lesson curriculum, it is suggested to give examples from daily life in the teaching of integers.

Methodology: In the research; An in-depth investigation was made about how teachers explain the issue of integers, whether they use models, the benefits and shortcomings of the models they use, and their knowledge about different models. For this reason, a case study (case study), which is one of the qualitative research methods, was conducted in order to obtain teachers' views on modeling the integer issue. The study group of the research; It consists of Secondary School Mathematics teachers working in the same region, determined by taking into account their years of service, gender and the institutions they work in. An interview form consisting of open-ended questions was used as a data collection tool. The application started after the necessary studies for its validity and reliability were completed. Semi-structured interviews were conducted with the teachers reached in the study. The "Descriptive Analysis Method" was used in the study because the obtained data were summarized and interpreted according to the previously determined conceptual framework or themes.

Results and Conclusions: The results of the research are similar to the information obtained in the literature review. With the information obtained, all of the research questions created were answered.

It was seen that the teachers explained the subject of integers by modeling. The models used are generally the same. The most used model is number stamps and the profit and loss context. It has been observed that the models used are useful in understanding the subject. It is emphasized that modeling embodies learning and makes it permanent. In addition, it is mentioned that misconceptions are prevented by modeling. It is mentioned that modeling is insufficient in some subjects. In particular, difficulty is encountered when modeling the extraction and division process. It was stated that this situation stems from the nature of the subject. It was stated that some models are 
more useful in explaining different parts of the subject. For example, it is more convenient to use counting stamps for addition and subtraction. It was observed that the teachers did not have information about different models. In short, modeling is useful in lecture. However, the models used are insufficient in modeling the whole subject. 